\title{
Faith and Property Rights: Discussion on the Legality of Virtual Identity and Property Rights Distribution
}

\author{
Xiangzhuo Wang \\ Universiti Teknologi Malaysia, Hengshui College, Hengshui, China \\ Email: 15830166900@163.com
}

How to cite this paper: Wang, X. Z (2021). Faith and Property Rights: Discussion on the Legality of Virtual Identity and Property Rights Distribution. Advances in Applied Sociology, 11, 281-289.

https://doi.org/10.4236/aasoci.2021.115025

Received: April 20, 2021

Accepted: May 25, 2021

Published: May 28, 2021

Copyright $\odot 2021$ by author(s) and Scientific Research Publishing Inc. This work is licensed under the Creative Commons Attribution International License (CC BY 4.0).

http://creativecommons.org/licenses/by/4.0/

\begin{abstract}
This article combs through many documents on property rights analysis in recent years, discusses existing property rights analysis from three dimensions: the shaping mechanism of property rights, the existence form of property rights, and the social nature of property rights, revealing the endogenous and outreach of the rules of property rights Evolution mechanism. And from the perspective of typology, it interprets the intersubjectivity of the construction of property rights and the legal role of virtual identity in the distribution of property rights, and points out that property rights are not only a lubricant for social stability, but also an accelerator for national economic development. The article points out that this duality of property rights is manifested in the collusion of power and authority in terms of legitimacy, and abstracted into the interweaving of ideology and social belief in terms of rationality. It plays an important role in the distribution and protection of rights. Although existing research usually regards property rights as the basic concept of economics, they cannot ignore the social, political, and legal process of property rights. Therefore, the discussion of the legality of virtual identity in the distribution of property rights is the main reason to understand the process of property rights realization and also an important concept for analyzing the relationship between social beliefs and property rights.
\end{abstract}

\section{Keywords}

Faith, Property Rights, Virtual Identity, Distribution of Property Rights

\section{Introduction}

"Property rights" are usually understood as "rights of property" (Veseth, 1982; Carruthers \& Ariovich, 2004; Walder, Luo, \& Wang, 2013; Justesen, 2014), ex- 
isting studies on "property" can include two aspects: one is the orientation of "property", which is divided into two levels. On the one hand, it is the discussion of intangible property, namely information (Wunderlich, 1974) and knowledge (Breakey, 2010; Adkisson, 2004), etc. On the other hand, it is the discussion of tangible property, namely resources (Schaber, 2011), prisoners (Frey \& Buhofer, 1988), slaves (Lagerlöf, 2009), etc.; the second is the main discussion of "property", namely the country (Carruthers \& Ariovich, 2004; Walder, Luo, \& Wang, 2013), the enterprise (Merrill, 2002), individuals (Elegido, 1995), etc. Property rights are understood as "rights" in economics. First, the concept of transaction costs (Coase, 1960) is introduced, and transaction costs are taken as the prerequisite basis for the existence of property rights, and its exclusivity, clarity, and availability are analyzed. Transferability (Alchain \& Demsetz, 1972), as an incentive mechanism to improve economic performance. However, property rights are understood as a "relationship" in sociology (Zhou, 2005) and used as a reactive mechanism to adapt to changes in the social environment. Taking China's economic development during the transition period as an example, it formed a social construction theory on property rights analysis. The article believes that these three interpretations of property rights have their theoretical foundation and methodological support, but the article does not make any judgments on these concepts, but aims to find the sharing mechanism of these concepts, that is, the three dimensions of property rights analysis: shaping mechanism, existence social nature; reveal the internal mechanism of the intersubjectivity of property rights divided by subject identity and distribution rules. On this basis, the article explores the virtual identity of property rights, that is, the social foundation of non-factual subjects such as the state, society, and enterprises in the establishment of property rights rules.

\section{The Three Dimensions of Property Rights Analysis}

The article aims to discuss the sharing mechanism of the three concepts of property rights, and to shape property rights, that is, the roles of state power and social authority in the formation of property rights rules; the social nature of property rights, that is, the respective impacts of public and private ownership on social stability and economic performance. The respective effects of economic performance; the existence form of property rights, that is, the social moral and political basis for the coexistence of factual possession and nominal claims, and a sociological analysis of property rights.

\section{The Shaping of Property Rights: The Collusion of Power and Authority}

Max Weber defines "power" as "a person still has a certain ability to influence the behavior of others in the face of opposition from others", that is, power means that no matter what the reason is, in a certain social relationship one should carry out his own will and eliminate all opportunities for resistance. It involves a wide range. It can refer to the discipline of the children by the parents 
in the family, or the orders of the superiors to the subordinates in any organization. The article mainly uses the concept of power to illustrate the way in which the strong establish the rules of property rights. "Property rights are not only the product of law and social traditions, but also things shaped by competing interest groups through political actions and negotiations. The positions taken by influential participants and the concessions they make to reach an agreement determine the political outlook of the property rights system in any era" (Libecap, 2001). Similar studies include: "The property right system must be a political system. Regardless of the past or the present, the nature and implementation of the power structure are determined by political forces" (Alston, 2003), "The property rights are ultimately based on the ability to forcefully exclude potential competitors; it is power, not fairness, that determines society Definition of the property rights of resources" (Umbeck, 1981).

Of course, some studies have used quantitative methods to reveal the insignificance of power in the establishment of property rights rules. "The national laws of Ghana and Côte d'Ivoire have hardly any substantial impact on property rights institutions" (Bubb, 2013). Therefore, another concept has to be introduced, namely "authority". Weber interprets "authority" as legalized power. The article uses the concept of authority to explain the influence of informal norms formed by the rules of property rights, and analyzes the interweaving relationship between state power and social authority from a concrete perspective. It also points out that the endowment of authority is the simple habitual response of social actors-the purest rational balance-of-interests pedigree of "Pareto choice", "customary law violation of female family property" (Ajayi \& Olotuah, 2005); "In terms of land transfer for growing cash crops, the importance of non-state regulations is more prominent" (Bubb, 2013) “ownership not only means rights, but also includes inherent restrictions and obligations" (Elegido, 1995).

How do we understand the effect of the two forces on the arrangement of rights attached to the objects in the formation of property rights rules? The article analyzes the formation mechanism of property rights rules with the following propositions: 1) the clear rules of property rights are either strong powers that are established by the state, or weak powers that are established by customary laws; 2) in order to meet the needs of social development and stability, the establishment of rules is often The product of collusion between formal norms and customary law; 3) any state power that deviates from social authority is full of risks when establishing property rights rules.

\section{The Nature of Property Rights: The Struggle between Public and Private 0wnership}

Discussions of public and private property rights are often based on considerations of economic performance and social equality. The research analyzed from the perspective of economic performance includes: "The meaning of property rights is the core of economic language" (Cole \& Grossman, 2002). "The inefficient mechanism of capitalism" (Frech III, 1975) believe that if there is no de- 
centralized system of private property rights for the means of production, there will be a lack of opportunities for coordination, which is an inefficient incentive mechanism. "Markets with different structures even indicate that the structure of market actors will be given property rights" (Walder, Luo, \& Wang, 2013). "Politically influential elites may be more willing to give up power through democratization so that future decision makers can enforce property rights, thereby ensuring greater investment and faster growth" (Gradstein, 2007). "Power Distribution improves the protection of property rights, which in turn increases economic growth" (Justesen, 2014). The research analyzed from the perspective of social equality includes: "The effective and fair reshaping of property rights seems to require a political system to involve a wide range of democratic forces in decision-making" (Riskin, 2009). These studies use property rights as a tool to achieve economic growth, and discuss the social nature of property rights, that is, public or private: "If a single person owns land, he will consider the income and cost tendency at a certain time in the future, and he chooses the method that he believes can maximize the current value of his private land rights, thereby trying to maximize his current value. Public property means that future generations must speak for themselves, but no one can estimate the cost of conducting this conversation" (Demsetz, 1967). That is, private property rights can internalize external behaviors, thereby reducing unpredictable transaction costs caused by free-riding and negotiation, and maximizing economic benefits.

The article believes that whether it is private property rights or public property rights, their nature depends on the stage and level of a certain country's economic development and directly affects the goal of economic growth. "In the transition of national socialism, property rights are redistributed to organizations and groups, creating new markets and new forms of economic enterprises" (Walder, Luo, \& Wang, 2013); taking China as an example during the transition period, for example, "the 'fuzzy' nature of their property rights does not seem to hinder their economic vitality, but enhance their economic vitality" (Weitzman $\& \mathrm{Xu}, 1997)$. Therefore, the article points out that property rights are a tool of economic development, and the nature of property rights has undergone a public-mixed-private change in the corresponding level of economic development. That is, the understanding of the nature of property rights is mostly based on an effective assessment of the level of economic development of a country or region.

\section{The Form of Property Rights: The Coexistence of Factual Possession and Nominal Claim}

"Law and actual rights differ according to people's expectations. If their legal rights are not enforced (or unenforced), their behavior lacks its legal basis" (Maskin \& Tirole, 1999). The statement is based on a certain interpretation. The basis of rights behind the items is more based on the understanding of the legal level, that is, the mandatory restraint and understanding of the actions of the actors. In fact, when property rights are again understood as "rights", they have already portrayed the obligations behind the rights and the social moral founda- 
tion of the obligations. "The indivisibility of family property" (Fustel de Coulanges, 2006), based on the belief in the deceased, the peace and happiness of the ancestors and the undead are tied to the sacrifices made to them by descendants. Thus every family must pass on the incense forever, because people do not belong to themselves, they belong to the family. Therefore, the form of property rights is deeply constrained by the belief behind the rights.

The article believes that the division of the actual possession of property rights and the claim of names is the result of the interweaving of law, society, politics, and economy. "The fact that companies discharge harmful substances into the air shows that they will not be punished for it" (Ayyagari, Demirgüç-Kunt, \& Maksimovic, 2008), that is, there is a vague area between the use and the right of use at the legal level, but in the name and facts. There is a clear moral basis for possession: companies are given certain rights in the use of public resources due to social interests, but they must bear certain obligations and restrictions while enjoying the rights, such as protecting the environment and saving resources. The same division is also the result of the deepening of political power. Nominal endowment is a strategic choice to achieve social control. Factual possession is a stable mechanism for the state to protect the consistency of property rights and economic development. Therefore, the mechanism and social foundation behind the coexistence of the two should be examined from multiple dimensions.

\section{The Inter-Subjectivity of Property Rights Construction}

"Property rights are a bunch of relationships" (Zhou, 2005) regards property rights as a product of social constructivism, that is, an adaptive mechanism to the environment. The Chinese economy in the transitional period "has not 'resolved' the issue of property rights in the clear sense of private property rights, such as the ownership of 'township and village enterprises' in the rural industrial sector in the 1980s and 1990s: collective ownership or de facto private partners. The relationship is collective or some kind of joint venture between collective and private parties to avoid political penalties used to punish the private sector" (Riskin, 2009). How do we understand this "wearing a hat" property right arrangement? The article uses the concept of "intersubjectivity" to explain the interaction mechanism between the state and society, that is, property rights are the product of the relationship between the state and society in the historical pedigree. Therefore, the article mainly discusses the internal mechanism of the intersubjectivity of property rights from the perspective of the identity of property rights subjects and the rules of distribution.

\section{The Identity of the Subject of Property Rights: State-Society}

The state model of the new institutional economics is based on the assumption of maximum utility. On the one hand, the state defines the basic rules of competition and cooperation in the property rights structure and maximizes rents, on 
the other hand, it tries to reduce transaction costs to maximize social output. Thereby increasing national taxes. To a certain extent, the state is regarded as an economic man with welfare or utility maximization who is subject to the dual constraints of competition and transaction costs, pursuing rent maximization and maximizing the total output of the whole society (North, 1994). However, in most cases, the state provides inefficient property rights. "The political system has an innate tendency to form inefficient property rights, and this system leads to economic stagnation or recession" (North, 1990) and from incomplete information Interpretation of various transaction costs and the consequences of third-party actors. The article points out that these three issues actually respond to society's manifestations in the formulation of property rights rules.

From the perspective of the identity of the subject of property rights, the above figure contains two internal mechanisms: first, the state, as the establisher of property rights rules, that is, power rules, relies on power to establish the foundation in fact possession, and forms a certain ideology to strengthen power. Rules; second, society, as the coordinator of property rights rules, that is, weak power rules, relies on the value rationality of social members in fact possession, that is, the basis for establishing authority, and uses social beliefs as a stable mechanism. However, how to define the formation mechanism of rules requires an examination of the social interaction mechanism formed by the relationship between the state and society.

\section{Rules for the Distribution of Property Rights: Factual Possession-Nominal Claim}

The article divides the rules of property rights distribution into two categories: factual possession and nominal claim. This kind of rule is more common in developing countries during the transition period. Nominal claims are manifested as the manifestation of ideology at the national level. There are a lot of social conflicts and games due to the tension of ideological order; it manifests as the manifestation of faith at the social level. Take China's cemetery property rights as an example. The original owner enjoys the eternal right of use, which is the continuation mechanism of the traditional Chinese society in the belief system.

Factual possession can extract the role of power at the national level, that is, "property rights are ultimately based on the ability to use force to exclude potential competitors; it is power, not fairness, that determines the definition of the property rights of social resources" (Umbeck, 1981). At the social level, it manifests as authority, that is, the cognitive mechanism conferred by the majority of members of society in accordance with custom or customary law. However, as for the individual, "the party's bounded rationality, as well as the transaction costs of foreseeing, contracting, and executing the contract, cause the parties to only conclude an incomplete contract that cannot cover all possible situations" (Lamoreaux, 2011). This contradiction is not within the scope of this rule. However, a stable property rights mechanism can be understood as a conspiracy of power and authority, and deepening into the interweaving of ideology and belief. 


\title{
9. The Legality of Virtual Identity and Property Rights Distribution
}

\author{
Belief: the stabilizing role of informal norms in the evolution of property \\ rights.
}

“The infringement of customary law on women's family property" (Ajayi \& Olotuah, 2005), "In terms of land transfer for growing cash crops, the importance of non-state norms has been highlighted" (Bubb, 2013), "The indivisibility of family property" based on the belief in the deceased, the peace and happiness of the ancestor's undead are tied to the sacrifices made to them by descendants, so each family must pass on incense forever, so people do not belong to themselves. It belongs to the family, so the form of property rights is deeply constrained by the beliefs behind the rights. From these studies, we can find belief, that is, the social cognition that people have formed in the inheritance of history and the extension of the family, which has been internalized into the rules of behavior. Therefore, the introduction of "virtual identities" will take the subjects that do not exist in reality, and the "utopia" in people's minds, that is, the source of belief, will serve as the main basis for the distribution of property rights. It plays an important role in protecting families and stabilizing society in the evolution of property rights order and property rights rules.

Control: A strategic mechanism for the country to achieve social and economic development.

The article believes that the state's attitude towards property rights includes both protection factors and control mechanisms. "The state is the main body of the institutional arrangement of property rights" (North, 1994). On the one hand, it defines the basic rules of competition and cooperation in the structure of property rights to maximize rents. On the other hand, it reduces transaction costs to maximize social output, thereby increasing the state taxation. To a certain extent, the state is regarded as an economic man with welfare or utility maximization who is subject to the dual constraints of competition and transaction costs, pursuing rent maximization and maximizing the total output of the whole society. Therefore, from the perspective of this heavy interpretation, property rights can be regarded as a strategic mechanism for the country to achieve economic development. Take China's economic development during the transition period as an example. Unlike the simple property rights incentive mechanism emphasized by economics, China's rapid economic development is based on unclear property rights and has achieved a large amount of capital accumulation. According to the article, clear property rights is only a necessary condition for economic development, and the country's strategic arrangements are sufficient conditions.

\section{Conclusion}

Through combing through numerous documents, the article discusses the sharing mechanism of different concepts of property rights from the shape, social nature and existence of property rights, and through the division of typology, 
and interprets the intersubjectivity and virtual identity of property rights construction from the perspective of typology. The role of legality in the distribution of property rights points out that property rights are not only a lubricant for social stability, but also an accelerator of national economic development. Although existing research usually regards property rights as the basic concept of economics, they cannot ignore the social, political, and legal processes of property rights. Therefore, the discussion of the legality of virtual identity in the distribution of property rights is the main reason to understand the process of property rights realization. Content is also an important concept for analyzing the relationship between social beliefs and property rights.

\section{Conflicts of Interest}

The author declares no conflicts of interest regarding the publication of this paper.

\section{References}

Adkisson, R. V. (2004). Intellectual Property Rights in the Global Economy. Journal of Economic Issues, 38, 281-282. https://doi.org/10.1080/00213624.2004.11506680

Ajayi, M. A., \& Olotuah, A. O. (2005). Violation of Women's Property Rights within the Family. Agenda, 19, 58-63.

Alchian, A., \& Demsetz, H. (1972). Production, Information Costs, and Economic Organization. American Economic Review, 62, 777-795.

Alston, L., Mueller, B., \& Cosgel, M.M. (2003). Property Rights to Land. The Oxford Encyclopedia of Economic History, 4, 274-279.

Ayyagari, M., Demirgüç-Kunt, A., \& Maksimovic, V. (2008). How Well Do Institutional Theories Explain Firms' Perceptions of Property Rights? The Review of Financial Studies, 21, 1833-1871. https://doi.org/10.1093/rfs/hhl032

Breakey, H. (2010). Natural Intellectual Property Rights and the Public Domain. The Modern Law Review, 73, 208-239. https://doi.org/10.1111/j.1468-2230.2010.00791.x

Bubb, R. (2013). The Evolution of Property Rights: State Law or Informal Norms? The Journal of Law \& Economics, 56, 555-594. https://doi.org/10.1086/673208

Carruthers, B. G., \& Ariovich, L. (2004). The Sociology of Property Rights. Annual Review of Sociology, 30, 23-46. https://doi.org/10.1146/annurev.soc.30.012703.110538

Coase, R. H. (1960). The Problem of Social Cost. In C. Gopalakrishnan (Ed.), Classic Papers in Natural Resource Economics (pp. 87-137). London: Palgrave Macmillan. https://doi.org/10.1057/9780230523210_6

Cole, D. H., \& Grossman, P. Z. (2002). The Meaning of Property Rights: Law versus Economics? Land Economics, 78, 317-330. https://doi.org/10.2307/3146892

Demsetz, H. (1967). Towards a Theory of Property Rights. The American Economic Review, 57, 347-359.

Elegido, J. M. (1995). Intrinsic Limitations of Property Rights. Journal of Business Ethics, 14, 411-416. https://doi.org/10.1007/BF00872103

Frech III, H. E. (1975). Property Rights and the Dynamic Inefficiency of Capitalism Comment. Journal of Political Economy, 83, 209-213.

Frey, B. S., \& Buhofer, H. (1988) Prisoners and Property Rights. The Journal of Law \& 
Economics, 31, 19-46. https://doi.org/10.1086/467148

Fustel de Coulanges (2006). La cités antique: Étude sur le culte, le droit, les institutions de la Grème et de Rome. Shanghai: East China Normal University Press.

Gradstein, M. (2007). Inequality Democracy and the Protection of Property Rights. The Economic Journal, 117, 252-269. https://doi.org/10.1111/j.1468-0297.2007.02010.x

Justesen, M. K. (2014). Better Safe than Sorry: How Property Rights and Veto Players Jointly Affect Economic Growth. Comparative Politics, 46, 147-167. https://doi.org/10.5129/001041514809387360

Lagerlöf, N. P. (2009). Slavery and Other Property Rights. The Review of Economic Studies, 76, 319-342. https://doi.org/10.1111/j.1467-937X.2008.00511.x

Lamoreaux, N. R. (2011). The Mystery of Property Rights: A U.S. Perspective. The Journal of Economic History, 71, 275-306. https://doi.org/10.1017/S0022050711001537

Libecap, G. D. (2001). Contracting for Property Rights (pp.5-15). Beijing: China Social Sciences Press.

Maskin, E., \& Tirole, J. (1999). Two Remarks on the Property-Rights Literature. The Review of Economic Studies, 66, 139-149. https://doi.org/10.1111/1467-937X.00081

Merrill, T. W. (2002). Introduction: The Demsetz Thesis and the Evolution of Property Rights. The Journal of Legal Studies, 31, S331-S338. https://doi.org/10.1086/374348

North, D. C. (1990). Institutions, Institutional Change and Economic Performance. Cambridge: Cambridge University Press. https://doi.org/10.1017/CBO9780511808678

North, D. C. (1994). Structure and Changes in Economic History (pp. 3-15). Shanghai: Shanghai Sanlian Publishing House, Shanghai People's Publishing House.

Riskin, C. (2005). Property Rights and the Social Costs of Transition and Development in China. Economic and Political Weekly, 43, 37-42.

Schaber, P. (2011). Property Rights and the Resource Curse Global Governance. The Governance of Extractive Resources, 17, 185-196. https://doi.org/10.1163/19426720-01702006

Umbeck, J. (1981). Might Makes Rights: A Theory of the Formation and Initial Distribution of Property Rights. Economic Inquiry, 19, 38-59.

https://doi.org/10.1111/j.1465-7295.1981.tb00602.x

Veseth, M. (1982). The Economics of Property Rights and Human Rights. American Journal of Economics and Sociology, 41, 169. https://doi.org/10.1111/j.1536-7150.1982.tb03169.x

Walder, A. G., Luo, T. J., \& Wang, D. (2013). Social Stratification in Transitional Economies: Property Rights and the Structure of Markets. Theory and Society, 42, 561-588. https://doi.org/10.1007/s11186-013-9203-2

Weitzman, M., \& Xu, C. (1997). Chinese Township-Village Enterprises as Vaguely Defined Cooperatives. In: J. E. Roemer (Ed.) Property Relations, Incentives and Welfare. International Economic Association Series. London: Palgrave Macmillan. https://doi.org/10.1007/978-1-349-25287-9_12

Wunderlich, G. (1974). Property Rights and Information. The Annals of the American Academy of Political and Social Science, 412, 80-96. https://doi.org/10.1177\%2F000271627441200109

Zhou, X. G. (2005). Relationship Property Rights: A Sociological Explanation of Property Rights System. Sociological Research, No. 2, 1-31, 243.

http://doi.org/10.19934/j.cnki.shxyj.2005.02.001 